\title{
Enhancing Organic Continuance Intentions of Organic Coconut Sugar Technology
}

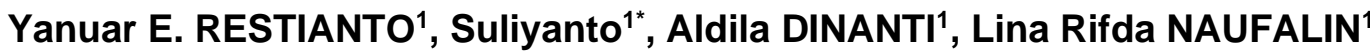 \\ ${ }^{1}$ Economics and business faculty, Jenderal Soedirman University, Purwokerto, Indonesia \\ E-mail: suliyanto@unsoed.ac.id \\ * Corresponding Author
}

\author{
Received: 25.07.2021 Accepted: 31.08.2021 Published: 11.10.2021 DOI: $\underline{\text { 10.47750/QAS/22.184.18 }}$
}

\begin{abstract}
Indonesia is the largest producer of coconut sugar in the world. However, the welfare of coconut sugar farmers in Indonesia is still low. One of the causes of the low welfare of coconut sugar farmers in Indonesia is because they are not able to meet the organic requirements of the export market. The low ability to meet organic requirements for coconut sugar is due to the low number of farmers who are adopting organic coconut sugar technology. The purpose of this study was to investigate the factors that influence the intention to continue adopting organic coconut sugar technology. This research was conducted in Purbalingga, Indonesia with 104 samples of organic coconut sugar farmers. Data were collected using a questionnaire with measurements using a 5 Likert Scale. Structural Equation Modeling with Partial Least Square (PLS) was used to test the causal relationship between constructs. The results of the study prove that organic perceived usefulness (OPU) has a positive effect on organic technology user satisfaction (OTUS) and on organic continuance intention (OCI), organic of perceived ease of use (OPEU) does not have a positive effect on organic technology user satisfaction (OTUS) but has positive effect on organic continuity intention (OCI), organic perceived risk (OPR) has a negative effect on organic technology user satisfaction (OTUS) and on organic continuity intention (OCI), while organic technology user satisfaction (OTUS) has a positive effect on organic continuance intention ( $\mathrm{OCl}$ ). The managerial implication to encourage the adoption of organic coconut sugar is to always socialize the advantages of organic coconut sugar and continue to provide counseling about organic coconut sugar technology and how to reduce risks in organic coconut sugar business to the farmers of coconut sugar.
\end{abstract}

Keywords: Organic coconut sugar, organic perceived of usefulness, organic perceived ease of use, organic perceived risk, organic technology, user satisfaction, and organic continuance intention

\section{Background}

Coconut sugar is a srongly potential source to be developed in Indonesia as the largest coconut sugar producing country in the world with 120,000 tons production capacity per year (Suliyanto et al, 2019). However, the welfare of coconut sugar farmers in Indonesia is still low. (Suliyanto, 2013; Suliyanto, et al., 2013). One of the causes of the low welfare of coconut sugar farmers in Indonesia is due to products that do not meet the international market demand (Suliyanto, 2019), so that many Indonesian coconut sugar products are only marketed domestically with lower business margins than if they are marketed on the internationally. Nowadays, international market demands for organic coconut sugar. As a resullt, organic coconut sugar is one of the creative industries that has great export market prospects.

Furthermore, the hype of a back-to-nature lifestyle and growing public awareness of the adverse effects of using chemicals on agricultural inputs (Jahroh, 2011) encourage consumers, especially middle-upper consumers to consume healthy food for their health reasons and choose goods that are more friendly in production process. The implication of this phenomenon is the increasing demand for organic products, including organic coconut sugar products. The high demand for organic coconut sugar from the export market has not yet been fulfilled due to the production of organic coconut sugar which has not been able to meet the demand for the export market. The low production of organic coconut sugar in Indonesia is caused by the low level of adoption of organic coconut sugar technology that is closely related to the perception of coconut sugar farmers towards organic coconut sugar technology.

Rogers (2003) with the theory of diffusion of innovation (DOI) stated that adoption is a decision-making process. Farmers will make a number of considerations by evaluating the advantages and disadvantages of an innovation, therefore, farmers need time to study, understand, or try the introduced innovation. Farmers' perceptions of organic coconut sugar technology innovation characteristic become very important as a basis for making decisions to accept or to reject an innovation. If the characteristics of the innovation have conformity with the expected perception, the innovation will be easily accepted and vice versa. Rogers (2003) stated that the characteristics of innovation include comparative advantage, compatibility, complexity, triability, and observability, while Davis (1989) stated that the characteristics of technology consist of perceived usefulness and perceived ease of use, both of them can affect 
attitudes and intentions to adopt new inovation.

There have been many studies examining perceptions of technology adoption by testing the effect of perceived ease of use (PEU) and perceived usefulness (PU) on behaviora intention to use. In general, PEoU has a positive effect on behavioral intention to use (Agarwal \& Prasad, 1999; Davis, 1989; Venkatesh et al., 2000) and perceived usefulness also has a positive effect on behavioral intention to use (Venkatesh et al, 2000). Generally, the research was conducted on information technology (Rani et al., 2014), while research that examines the adoption of technology in agriculture, especially the adoption of organic coconut sugar technology is still limited, so it is necessary to conduct research with the aim of analyzing the effect of the perception of coconut sugar farmers on using organic coconut sugar technology needs to be done.

\section{Literature Review and Hypothesis}

\subsection{Technology Acceptance Model (TAM) Theory}

The main theory used in this study is the Technology Acceptance Model (TAM) theory, which is a behavioral theory that explains the approach to the use of information technology, which was developed by Davis (1989). The Technology Acceptance Model (TAM) is an adaptation of the Theory Reasoned Action (TRA) developed by Fishbein and Ajzen (1977). The Technology Acceptance Model (TAM) develops a framework regarding interest in using information technology based on perceived usefulness and perceived ease of use. Technology Acceptance Model (TAM) has been widely used to test user behavioral intentions, acceptance and adoption of new technologies by considering two important constructs that are perceived usefulness and perceived ease of use ( $\mathrm{Li}$ and Yeh, 2010). The TAM developed by Davis (1989) has been most frequently utilized in explaining the use and use behavior of information technology (Kim and Lee, 2014). Besides using perceived benefits and convenience factors for interest in using technology, this study adds a risk perception factor in the Technology Acceptance Model (TAM) framework to determine the effect of perceived risk on interest in continuing to use organic coconut sugar technology.

\subsection{Organic Technology User Satisfaction (OTUS)}

User satisfaction is a difficult, intangible and elusive concept to define, but the definition of user satisfaction is indispensable for research on system performance and user experience (Griffiths, 2007). Initially, Tessier et al., (1977) stated that satisfaction is 'ultimately a state experienced inside the user's head'. User satisfaction is an important criterion for measuring the success of a technology adoption. Several previous researchers have defined satisfaction, such as Seddon (1997) defined satisfaction as a subjective evaluation of various consequences (individual, organizational, social consequences of IS use) evaluated using a pleasant-unpleasant continuum evaluated line, while Fornell (1992), stated that customer satisfaction was a mental state that occurred from a comparison between pre-purchase expectations and post-purchase perceived performance. Crosby et al. (1990) stated that satisfaction was an 'emotional state that occurred in response to an evaluation of these interactive experiences. Previous researchers had defined user satisfaction related to the use of information technology and information systems. (Doll and Torkzadeh, 1988; Seddon and Kiew; 1994). In this study, organic technology user satisfaction (OTUS) was defined as the feeling of pleasure or displeasure with the organic coconut sugar technology after comparing the expectations and the performance of the organic coconut sugar technology.
Satisfaction is a function of expectations and reality (Zhang and Prybutok (2005). Some studies use one item to measure overall satisfaction (Selnes \& Hansen, 2001), while others use multiple items to measure satisfaction (Kim, 2002; Oliver, 1980). Research showed that satisfaction with purchasing decisions is related to attitudes and behavior.

\subsection{Organic Perceived Usefulness (OPU)}

Perceived usefulness (PU) is a belief in usefulness or the degree to which users believe that the use of technology/systems will improve their performance at work (Davis et al., 1989; Ajzen, 1991; Venkatesh et al, 2003; Chen et al., 2007). ). In this study, organic perceived usefulness (OPU) is defined as the coconut sugar farmers' belief in the benefits or benefits derived from using organic coconut sugar technology.

In the TAM theory, Perceived usefulness is hypothesized as a direct predictor of behavioral intention to use $(\mathrm{BI})$ of the technology of interest (Park, et al., 2014). The results of previous studies indicated that perceived usefulness had a positive effect on continuity intention in various contexts, such as: (Chou, Min, Chang, \& Lin, 2009) on knowledge creation, (Wang, Ngai, \& Wei, 2011) on instant messaging; (Lin \& Wang, 2012) on e-learning, (Li \& Liu, 2014) on online travel services, (Baker-Eveleth \& Stone, 2015; Stone \& Baker-Eveleth, 2013) on electronic textbooks; and Hamid, et al., (2016) on e-government.

Previous research has proven the relationship between perceived usefulness and user satisfaction. Mawhinney and Lederer (1990) stated that user satisfaction has a strong relationship with perceived usefulness. Seddon and Kiew (1994) mentioned that perceived usefulness has a positive effect on user satisfaction. Rai et al., (2002) proved that perceived usefulness is positively related to user satisfaction. Hsu and Chiu (2004) stated that perceived usefulness is a determinant factor of user satisfaction in their research. Calisir \& Calisir (2004) found that perceived usefulness significantly impacts user satisfaction in an enterprise resource planning context.

Fairweather and Campbell (1996) stated that farmers will not consider implementing organic farming if farmers do not feel the problem with conventional farming and conventional farming is still profitable. Padel (2001) one of the motivations of farmers to change their farming system to organic is financial motives. If organic coconut sugar farmers feel that they believe that organic coconut sugar technology is useful, they will continue to adopt it. On the other hand, if they feel that organic coconut sugar technology is not useful, they will stop adopting it. Based on the results of previous studies, the first and the second hypotheses can be formulated as follows:

$\mathrm{H} 1$ : Organic perceived usefulness has a positive effect on organic technology user satisfaction

H2: Organic perceived usefulness has a positive effect on organic continuance intention

\subsection{Organic Perceived Ease of Use (OPEU)}

Perceived ease of use (PEU) is the degree or the level to which a person believes that using a technology is easy and does not require much effort from the user (Davis, 1989), while Saade \& Bahil, (2005) stated that PEU is the degree to which a person believes that an innovation is free from effort. In this study, Organic Perceived ease of use (OPEU) is the level of confidence of organic coconut sugar farmers that using organic coconut sugar technology is easy and does not require any hard work.

Several research results have proven that perceived ease of use had a positive effect on customer satisfaction in several contexts: Rezaei \& Amin (2013) on online shopping, (Amin at al, 2014), on mobile users' Lee and Jun, (2007) on mobile commerce, and Rani et al., (2014) on the Learning Management 


\section{System.}

Studies indicated that perceived ease of use is positively associated with continuance intention in various contexts such as (Chiu \& Wang, 2008) on Web-based learning, Hamid, et al., (2016) in the context of e-government. Based on previous research, the third and fourth hypotheses can be formulated as follows:

H3: Organic perceived ease of use has a positive effect on organic technology user satisfaction

$\mathrm{H} 4$ : Organic perceived ease of use has a positive effect on organic continuance intention

\subsection{Organic Perceived Risk (OPR)}

In addition to the perceived benefits and perceived ease of use factors, which affect interest in using technology, there is the perception of risk. Since the 1960s, the theory of perceived risk has been used to explain behavior (Lee., 2009). Risk perception is defined as the decision maker of the risk that happens in the situation (Sitkin and Pablo, 1992). Another understanding of perceived risk is the perception of uncertainty and the consequences that will be faced after carrying out certain activities (Hsu and Chiu, 2004:362). Perceived risk is a perception of uncertainty and undesirable consequences in carrying out an activity (Hsu and Chiu 2004:362). Risk perception is used as a substitute for risk because it is difficult to capture risk as a definite target. In this study, organic perceived risk (OPR) is defined as coconut sugar farmers' perceptions of the uncertainty and undesirable consequences of using organic coconut sugar technology.

According to Sjöberg et al (2004), risk perception is a subjective assessment of the probability of the type that specifies an accident that occurs and a worry about the consequences it will cause. Risk perception involves evaluating the likelihood of the consequences of a negative outcome. Perception of risk leads to beliefs about possible gains or losses beyond the considerations that include the relationship with trust in particular (Mayer et al, 1995).

Previous research that examined the relationship between perceived risk and user satisfaction, found that there was a negative correlation between perceived risk and perceived quality on e-commerce and also quality causes customer satisfaction Zhang and Prybutok (2005). Meanwhile, Tzavlopoulos (2019) stated that perceived risk had a negative effect on user satisfaction. Zhang and Prybutok (2005), stated that there is a negative relationship between perceived risk and customer satisfaction on e-commerce.

Although technology provides many benefits and ease of use for its users, it turns out that there are still a number of users who refuse to use technology because of uncertainty and security issues (Kuisma et al., 2007; Littler and Melanthiou, 2006). Perceived risk theory stated that consumers tend to minimize perceived risk rather than maximize benefits (Mitchell, 1999). Previous research stated that perceived risk has an effect on purchasing decisions and behavior (Chaudhuri, 1997; Mitchell, 1992). Their perception of risk (perceived risk) will also affect adoption behavior. The greater the perception of risk, the less the perception of the benefits for technology adoption (Gefen et al., 2003). According to Padel (2001), low risk is one of the characteristics that an innovation must have in order to be easily adopted. The lower perceived risk tends to increase the possibility of purchasing and increase purchase intentions, so that perceived risk has a negative effect on intentions (Wood and Scheer, 1996; Mitchell, 1999; Chang and Chen, 2008).

Risk is one major component that determines whether a person will buy a product or not (Cox, 1967) and technology imposes unique risks to consumers. Numerous studies provided empirical evidences that perceived risks exert a systematic and significant influence on beliefs, attitudes, and behavioral intentions (Jarvenpaa, 1996; Pavlou, 2003)

$\mathrm{H} 5$ : Organic perceived ease of use has a negative effect on organic technology user satisfaction

H6: Organic perceived ease of use has a negative effect on organic continuance intention

\subsection{Organic Continuance intention $(\mathrm{OCl})$}

Continuance intention $(\mathrm{Cl})$ is part of buying behavior where in the context of repurchase interest, there is the concept of loyalty (Souderlund and Vilgon, 1999). Behavioral interest or interest in use is defined as the level of how strong a person's desire or encouragement to perform a certain behavior (Davis et al, 1989). In this study, organic continuance intention (OCl) is defined as the desire or encouragement of organic coconut sugar farmers to continue using organic coconut sugar technology.

Several previous studies have stated that satisfaction has a positive effect on continuance intention in various different contexts. Thong, Hong, and Tam (2006) stated that continuance intention towards e-government services is influenced by satisfaction. Wen, Prybutok, and Xu's (2011) research revealed that satisfaction has a positive effect on online repurchase intention. Lee and Kwon (2011) also found that satisfaction had a positive effect on continuance intention on web-based services, Zhao \& Cao, (2010) stated that intention to continue was directly influenced by satisfaction, Rani et al., 2014 revealed that e-satisfaction has a positive effect on e-retention on the Learning Management System (LMS) and Mouakket, S. (2015) stated that satisfaction has a positive influence on continuance intention toward Facebook. Wixom and Todd (2005) found that user satisfaction and intention to use technology. Based on the results of previous studies, the fifth hypothesis can be formulated as follows:

$\mathrm{H7}$ : Organic technology user satisfaction has a positive effect on organic Continuance intention

\section{Method}

\subsection{Data Collection}

The target populations in this study were organic coconut sugar farmers in Purbalingga, Indonesia. Random sampling method was used as sampling technique, with 120 respondents as the samples. Data collection was done using a questionnaire. There were 120 questionnaires distributed, but only 104 were deserved to be analyzed.

\subsection{Measures}

Variable measurement was adopted from several previous studies, to measure organic perceived ease of use (OPEU) was developed from (Davis et al., 1989), to measure organic perceived usefulness (OPU) was developed from (Wang and Liao, 2007; Davis et al. , 1989), to measure organic perceived risk (OPR) was developed from (Tzavlopoulos at al., 2019), to measure organic technology user satisfaction (OTUS) was developed from online transaction satisfaction from (Wang and Liao, 2007), while to measure organic continuance intention (OCI) was developed from (Bhattacherjee, 2001; Kim, 2010). Measurement using 5 Likert scale in which 1 indicates "Strongly Disagree" and 5 indicates "Strongly Agree" with the mid-point (3) represents neutrality.

\subsection{Analysis}

In this study, the internal consistency was analyzed using 


\section{GENERAL MANAGEMENT}

cronbach's alpha (Cronbach's 1951; Nunnally, 1978), while convergent validity was assessed using factor loading, Composite Reliability (CR) and Average Variance Extracted (AVE) (Fornell \& Larcker, 1981). Structural Equation Modeling validity test with Partial Least Square (PLS) was used to test the causal relationship between constructs.

\section{Result And Discussion}

\subsection{Profile of the Respondents}

Based on the demographic characteristics, the average age of the respondents was 44,452 years old. They were not in young ages anymore. It indicates that there was a problem with the regeneration of coconut sugar farmers. In the average, they have become coconut sugar farmers for 14,337 years. It indicated that they already have a lot of experience as farmers, but they have only been organic coconut sugar farmers for 2,817 years, indicating that they have recently switched from conventional coconut sugar to organic coconut sugar. The average number of coconut trees that were producing coconut sugar per day were 28,913 trees, this showed that the number of coconut trees that were harvested was not that much, because the coconut sugar business was a side business other than as a farmer. The average number of family members was 4,548 people, this showed that by doing coconut sugar business, they were able to support about 5 family members. Most of the farmers were graduated from elementary school. They were 94,231 percent, this was because of those who have higher education prefer to work in more promising sectors such as working in private companies or being civil servants. Most of the coconut trees that were used as coconut sugar producer were rented, reaching about 61,538 percent. This was because not all of the farmers had their own coconut trees, while the owners of coconut trees are unable to do the production themselves because they were busy with other activities. All farmers or 100 percent were familiar with organic coconut sugar technology from farmer groups. This showed that farmer groups were highly effective in socializing organic coconut sugar technology.

\begin{tabular}{|c|c|c|c|}
\hline Profile of the Respondents & Average & Minimum & Maksimum \\
\hline Age (years old) & 44.452 & 27 & 70 \\
\hline Period of becoming Coconut sugar farmer (year) & 14.337 & 1 & 42 \\
\hline $\begin{array}{l}\text { Period of becoming Organic Coconut sugar farmer } \\
\text { (year) }\end{array}$ & 2.817 & 1 & 6 \\
\hline The number of processed coconut trees (tree) & 28.913 & 7 & 61 \\
\hline & 4.548 & 2 & 10 \\
\hline & \multirow{2}{*}{\multicolumn{2}{|c|}{ Percentage (\%) }} & \\
\hline Educational Background & & & \\
\hline Uneducated & 1 & 0.962 & \\
\hline Elementary School & 98 & 94.231 & \\
\hline Junior High School & 5 & 4.808 & \\
\hline Senior High School & 0 & 0 & \\
\hline Higher Education/ University Student & 0 & \multirow[t]{2}{*}{0} & \\
\hline \multicolumn{3}{|l|}{ Coconut Tree Ownership Status } & \\
\hline Private Owner & 9 & \multirow{2}{*}{8.654} & \\
\hline Rent & 64 & & \\
\hline Profit Sharing & 11 & 10.577 & \\
\hline Combination & 20 & 19.231 & \\
\hline \multicolumn{4}{|l|}{$\begin{array}{l}\text { The stakeholder who introduce Organic Coconut } \\
\text { Sugar Technology }\end{array}$} \\
\hline Agricultural instructor & 0 & 0 & \\
\hline Farming Group & 104 & 100 & \\
\hline Mass Media & 0 & 0 & \\
\hline Fellow Farmers & 0 & 0 & \\
\hline Others & 0 & 0 & \\
\hline
\end{tabular}

Table 1: Profile of the Respondents

\subsection{Validity and Reliability of Measures}

\begin{tabular}{|c|c|c|c|c|c|c|}
\hline Variable & Indicator & $\begin{array}{l}\text { Loading } \\
\text { Factor }\end{array}$ & $\begin{array}{l}\text { Loading } \\
\text { Factor }\end{array}$ & $\begin{array}{l}\text { Cronbach } \\
\text { Alpha }\end{array}$ & $\begin{array}{l}\text { Composite } \\
\text { Reliability }\end{array}$ & AVE \\
\hline \multirow{6}{*}{$\begin{array}{l}\text { Organic Percieved of } \\
\text { Usefulness (OPU) }\end{array}$} & OPU_1 & 0.801 & 0.801 & 0.815 & 0.860 & 0.509 \\
\hline & OPU_2 & 0.737 & 0.736 & & & \\
\hline & OPU_3 & 0.786 & 0.787 & & & \\
\hline & OPU_4 & 0.599 & 0.600 & & & \\
\hline & OPU_5 & 0.648 & 0.649 & & & \\
\hline & OPU 6 & 0.684 & 0.684 & & & \\
\hline \multirow{4}{*}{$\begin{array}{l}\text { Organic Perceived Ease of } \\
\text { Use (OPEU) }\end{array}$} & OPEŪ_1 & 0.679 & 0.692 & 0.777 & 0.842 & 0.575 \\
\hline & OPEU_2 & 0.863 & 0.860 & & & \\
\hline & OPEU_3 & 0.426 & & & & \\
\hline & OPEU 4 & 0.810 & 0.802 & & & \\
\hline
\end{tabular}




\section{GENERAL MANAGEMENT}

\begin{tabular}{|c|c|c|c|c|c|c|}
\hline Variable & Indicator & $\begin{array}{l}\text { Loading } \\
\text { Factor }\end{array}$ & $\begin{array}{l}\text { Loading } \\
\text { Factor }\end{array}$ & $\begin{array}{l}\text { Cronbach } \\
\text { Alpha }\end{array}$ & $\begin{array}{l}\text { Composite } \\
\text { Reliability }\end{array}$ & AVE \\
\hline & OPEU_5 & 0.646 & 0.661 & & & \\
\hline \multirow{6}{*}{$\begin{array}{l}\text { Organic Percived } \\
\text { Risk (OPR) }\end{array}$} & OPR_1 & 0.399 & - & 0.727 & 0.830 & 0.554 \\
\hline & OPR 2 & 0.678 & 0.750 & & & \\
\hline & OPR 3 & 0.638 & 0.593 & & & \\
\hline & OPR_4 & 0.797 & 0.821 & & & \\
\hline & OPR_5 & 0.401 & - & & & \\
\hline & OPR_6 & 0.751 & 0.791 & & & \\
\hline \multirow{3}{*}{$\begin{array}{l}\text { Organic Technology User } \\
\text { Satisfaction (OTUS) }\end{array}$} & OTUS_1 & 0.917 & 0.918 & 0.902 & 0.939 & 0.836 \\
\hline & OTUS_2 & 0.925 & 0.925 & & & \\
\hline & OTUS_3 & 0.900 & 0.900 & & & \\
\hline \multirow{4}{*}{$\begin{array}{l}\text { Organic Continuance } \\
\text { Intention }(\mathrm{OCl})\end{array}$} & OCl_1 & 0.806 & 0.806 & 0.805 & 0.939 & 0.632 \\
\hline & $\mathrm{OCl} 2$ & 0.822 & 0.822 & & & \\
\hline & $\mathrm{OCl} 3$ & 0.669 & 0.669 & & & \\
\hline & OCl_4 & 0.870 & 0.870 & & & \\
\hline
\end{tabular}

Table 2: Validity and Reliability of Research Instruments Test

Based on table 2, it illustrated that in the first stage, there were several indicators that had a factor loading value of less than 0.5 , such as OPEU_3, OPR_1 and OPR_5 so that these indicators were excluded from the analysis. After the indicators that had a factor loading value which was less than 0.5 were removed from the analysis, then the analysis was done and all indicators were declared valid or acceptable to measure the variables in this study. It was beacuse all indicators had greater than 0.5 factor loading value (Hair., et al 2010) . Cronbach's alpha for all variables was above 0.6 , since cronbach's alpha which was above 0.6 was considered high reliability (Nunnally and Bernstein, 1994) and composite reliability (CR) for all variables was higher than 0.7 so that the instrument reliability of all research variables could be accepted or reliable (Hair et al., 2010) and the average variance extract (AVE) of all variables was higher than 0.5 so that the instrument reliability of all variables was considered very good (Hair et al., 2010).

\subsection{Finding}

Based on the results of the calculations in Table 3, the $Q$ Square value was obtained at 0.496 . This showed the large diversity of research data that could be explained by the research model was $49.6 \%$, thus, from these results, this research model could be declared to have goodness of fit in the moderate criteria because it was greater than 33\% (Chin, 1998).

\begin{tabular}{|l|l|l|l|}
\hline Variable & R Squares & R Adjusted & $\begin{array}{l}\text { Q-Square } \\
\text { =1-(1-R12) (1-R22) }\end{array}$ \\
\hline Organic Technology User Satisfaction (OTUS) & 0.197 & 0.173 & 0.496 \\
\hline Organic Continuance Intention (OCI) & 0.372 & 0.347 & \\
\hline
\end{tabular}

Table 3. R Square, R Ajusted dan Q-Square

To test the causal relationship between constructs, Structural Equation Modeling with Partial Least Square (PLS) was used, with the following results:

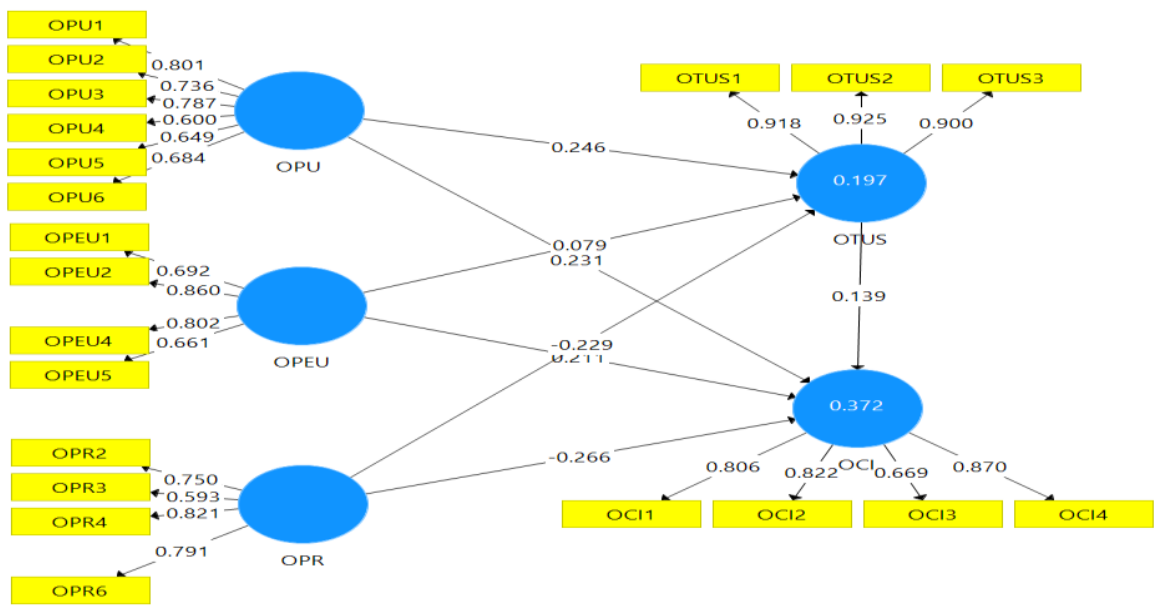

Figure 1: Result of Structural Equation Modeling 


\begin{tabular}{|c|c|c|c|c|c|c|}
\hline $\begin{array}{l}\text { Hypoth } \\
\text { esis }\end{array}$ & $\begin{array}{l}\text { Independent } \\
\text { Variable }\end{array}$ & Dependent Variable & $\begin{array}{l}\text { Original } \\
\text { Sample (0) }\end{array}$ & $\begin{array}{l}\mathbf{T} \\
\text { Statistic }\end{array}$ & $\begin{array}{l}P \\
\text { value }\end{array}$ & Result \\
\hline $\mathrm{H} 1$ & $\begin{array}{l}\text { Organic Percieved } \\
\text { of Usefulness }\end{array}$ & $\begin{array}{l}\text { Organic Technology } \\
\text { User Satisfaction }\end{array}$ & 0.246 & 3.238 & 0.001 & Support \\
\hline $\mathrm{H} 2$ & $\begin{array}{l}\text { Organic Percieved } \\
\text { of Usefulness }\end{array}$ & $\begin{array}{l}\text { Organic Continuance } \\
\text { Intention }\end{array}$ & 0.231 & 2.366 & 0.018 & Support \\
\hline H3 & $\begin{array}{l}\text { Organic Perceived } \\
\text { Ease of Use }\end{array}$ & $\begin{array}{l}\text { Organic Technology } \\
\text { User Satisfaction }\end{array}$ & 0.079 & 1.009 & 0.314 & Not Support \\
\hline $\mathrm{H} 4$ & $\begin{array}{l}\text { Organic Perceived } \\
\text { Ease of Use }\end{array}$ & $\begin{array}{l}\text { Organic Continuance } \\
\text { Intention }\end{array}$ & 0.211 & 2.396 & 0.017 & Support \\
\hline $\mathrm{H} 5$ & $\begin{array}{l}\text { Organic Percieved } \\
\text { Risk }\end{array}$ & $\begin{array}{l}\text { Organic Technology } \\
\text { User Satisfaction }\end{array}$ & -0.229 & 3.685 & 0.000 & Support \\
\hline $\mathrm{H} 6$ & $\begin{array}{l}\text { Organic Perceived } \\
\text { Risk }\end{array}$ & $\begin{array}{l}\text { Organic Continuance } \\
\text { Intention }\end{array}$ & -0.226 & 2.753 & 0.006 & Support \\
\hline $\mathrm{H} 7$ & $\begin{array}{l}\text { Organic } \\
\text { Technology User } \\
\text { Satisfaction }\end{array}$ & $\begin{array}{l}\text { Organic Continuance } \\
\text { intention }\end{array}$ & 0.139 & 2.012 & 0.045 & Support \\
\hline
\end{tabular}

Table 4: Hypothesis Test Result

Based on table 4, it was known that $\mathrm{H} 1, \mathrm{H} 2, \mathrm{H} 4, \mathrm{H} 5, \mathrm{H} 6$, and $\mathrm{H} 7$ were accepted because the $\mathrm{T}$ statistic value was greater than 1.96 or $\mathrm{P}$ Value was less than 0.05 , but $\mathrm{H} 3$ was not accepted because the $T$ statistic value was less than 1.96 or $P$ Value was greater than 0.05 .

\subsection{Discussion}

Organic perceived usefulness (OPU) had a positive effect on organic technology user satisfaction (OTUS) and on organic continuity intention $(\mathrm{OCl})$, this happened because by applying organic coconut sugar technology, farmers would get higher profits compared to conventional coconut sugar businesses, so that so they would continue to adopt organic coconut sugar technology. The results of this study were in line with research (Mawhinney and Lederer, 1990; Rai et al., 2002; Hsu and Chiu, 2004; Calisir \& Calisir (2004); Park et al., 2013; Amin at al., 2014 Ghazal et al. , 2017; Kim \& Lee, 2014), which stated that perceived usefulness had a positive effect on user satisfaction and (Park, et al., 2014; Chou, Min, Chang, \& Lin, 2009; Wang, Ngai, \& Wei, 2011; Lin \& Wang, 2012; Li \& Liu, 2014; BakerEveleth \& Stone, 2015; Stone \& Baker-Eveleth, 2013) which mentioned that perceived usefulness had a positive effect on continuance intention.

Organic perceived ease of use (OPEU) had a positive effect on organic continuity intention $(\mathrm{OCl})$, this happened because learning to use organic coconut sugar technology did not take long time and it was easy to apply so that they would continue to adopt organic coconut sugar technology. The results of this study were in line with researches (Viehland \& Leong, 2007; Lee and Jun, (2007; Rezaei \& Amin, 2013; Amin at al, 2014; Rani et al., 2014). However, it was found in this study that Organic perceived ease of use (OPEU) did not have a positive effect on organic technology user satisfaction (OTUS), this showed that convenience was not something that could satisfy coconut sugar farmers because satisfactory of technology was one that could provide high economic benefits with low risk while the level of difficulty could be learned. This finding was different from the results of research (Chiu \& Wang, 2008; Hamid, et al., (2016) which stated that perceived ease of use had a positive effect on continuance intention.

Organic perceived risk (OPR) had a negative effect on organic technology user satisfaction (OTUS) and on organic continuance intention $(\mathrm{OCl})$, this happened because if organic coconut sugar technology was considered to have a lot of uncertainty and higher risk compared to conventional coconut sugar technology then it would not satisfy organic coconut sugar farmers so they would stop adopting organic coconut sugar technology. The results of this study were in line with researches (Zhang and Prybutok (2005; Tzavlopoulos (2019; Zhang and Prybutok (2005),), which stated that perceived risk had a positive effect on organic technology user satisfaction (OTUS) and (Chaudhuri, 1997; Mitchell, 1992; Gefen et al., 2003; Padel (2001; Wood and Scheer, 1996; Mitchell, 1999; Chang and Chen, 2008) which stated that perceived risk had a positive effect on organic continuance intention $(\mathrm{OCl})$. organic technology user satisfaction (OTUS) and organic continuance intention $(\mathrm{OCl})$, this happened because if organic coconut sugar technology was considered to have a lot of uncertainty and higher risk compared to conventional coconut sugar technology, it would not satisfy organic coconut sugar farmers so that they would stopped adopting organic coconut sugar technology. The results of this study were in line with research (Zhang and Prybutok (2005; Tzavlopoul os (2019; Zhang and Prybutok (2005), which mentioned that perceived risk had a positive effect on organic technology user satisfaction (OTUS) and (Chaudhuri, 1997; Mitchell, 1992; Gefen et al., 2003; Padel (2001; Wood and Scheer, 1996; Mitchell, 1999; Chang and Chen, 2008) which stated that perceived risk had a positive effect on organic continuance intention $(\mathrm{OCl})$.

Organic technology user satisfaction (OTUS) had a positive effect on organic continuance intention $(\mathrm{OCl})$, this happened because if farmers were satisfied with applying organic coconut sugar technology because of the benefits, convenience, and low risk, they would continue to adopt organic coconut sugar technology. The results of this study were in line with research (Oliver, 1980; Thong, Hong, and Tam 2006; Wen, Prybutok, and Xu's, 2011; Lee and Kwon 2011; Zhao \& Cao, 2012; Rani et al., 2014: Mouakket, S. 2015), which stated that user satisfaction had a positive effect on continuance intention.

\subsection{Limitations and Suggestions for Future Research}

This study has not considered demographic factors and personality factors which in reality can affect acceptance of technology information, so that future research can add 
demographic variables such as: gender, age, race, marital status, income, religion, education level, place of residence and livelihood, also personality variables such as high innovation and low innovation as moderating variables between PeoU and PU on US.

\section{Conclusion}

Based on the results of data analysis, it can be concluded that organic perceived usefulness (OPU) has a positive effect on organic technology user satisfaction (OTUS) and on organic continuance intention (OCI), organic of ease of use (OPEU) does not have a positive effect on organic technology user satisfaction (OTUS), but it has a positive effect on organic continuance intention (OCI), organic perceived risk (OPR) has a negative effect on organic technology user satisfaction (OTUS) and on organic continuance intention $(\mathrm{OCl})$, while organic technology user satisfaction (OTUS) has a positive effect on organic continuance intention $(\mathrm{OCl})$. Based on these conclusions, farmers continue to adopt organic coconut sugar technology, stakeholders must be able to increase the satisfaction of the farmers by socializing the benefits of coconut sugar technology and providing assistance to farmers about organic coconut sugar business so that farmers will find it is easier to adopt organic coconut sugar technology and reduce the risk of failure.

\section{Acknowledgement}

Acknowledgments are addressed to the Education Funding Management Institute for providing research funding for the Innovative Productive Research Funding (Rispro) scheme, through the Institute for Community Service Research (LPPM) at Jenderal Sudirman University and for the Editor and the anonymous reviewers for their valuable comments and suggestions to this paper.

\section{References}

[1] Agarwal, R., \& Prasad, J. (1999). Are Individual Differences Germane to the Acceptance of New Information Technologies? Decision Sciences, 30(2), 361-391. doi: 10.1111/j.15405915.1999.tb01614.x

[2] Ajzen, I. (1991). The theory of planned behavior. Organizational Behavior and Human Decision Processes, 50(2), 179-211. doi: 10.1016/0749-5978(91)90020-t

[3] Amin, M., Rezaei, S., \& Abolghasemi, M. (2014). User satisfaction with mobile websites: the impact of perceived usefulness (PU), perceived ease of use (PEOU) and trust. Nankai Business Review International, 5(3), 258-274. doi: 10.1108/nbri-01-2014-0005

[4] Amin, M., Rezaei, S., \& Abolghasemi, M. (2014). User satisfaction with mobile websites: the impact of perceived usefulness (PU), perceived ease of use (PEoU) and trust. Nankai Business Review International. http://doi.org/ 10.1108/NBRI-012014-0005

[5] Baker-Eveleth, L., \& Stone, R. W. (2015). Usability, expectation, confirmation, and continuance intentions to use electronic textbooks. Behaviour \& Information Technology, 34(10), 9921004. doi: 10.1080/0144929x.2015.1039061

[6] Bhattacherjee, A. (2001). Understanding Information Systems Continuance: An Expectation-Confirmation Model. MIS Quarterly, 25(3), 351. doi: 10.2307/3250921

[7] Calisir, F., \& Calisir, F. (2004). The relation of interface usability characteristics, perceived usefulness, and perceived ease of use to end-user satisfaction with enterprise resource planning (ERP) systems. Computers in Human Behavior, 20(4), 505-515. doi: 10.1016/j.chb.2003.10.004

[8] Hsin Chang, H., \& Wen Chen, S. (2008). The impact of online store environment cues on purchase intention. Online Information Review, 32(6), 818-841. doi: 10.1108/14684520810923953

[9] Chaudhuri, A. (1997). Consumption Emotion and Perceived Risk: A Macro-Analytic Approach. Journal of Business Research, 39(2), 81-92. doi: 10.1016/s0148-2963(96)00144-0

[10] Chen, Q., Chen, H.-M., \& Kazman, R. (2007). Investigating antecedents of technology acceptance of initial eCRM users beyond generation $\mathrm{X}$ and the role of self-construal. Electronic Commerce Research, 7(3-4), 315-339. doi: 10.1007/s10660007-9009-2

[11] Chin, W. W. (1998). The partial least squares approach to structural equation modeling. Modern methods for business research, 295(2), 295-336.

[12] Chiu, C.-M., \& Wang, E. T. G. (2008). Understanding Web-based learning continuance intention: The role of subjective task value. Information \& Management, 45(3), 194-201. doi: 10.1016/j.im.2008.02.003

[13] Chou, S.-W., Min, H.-T., Chang, Y.-C., \& Lin, C.-T. (2010). Understanding continuance intention of knowledge creation using extended expectation-confirmation theory: an empirical study of Taiwan and China online communities. Behaviour \& Information Technology, 29(6), 557-570. doi: 10.1080/01449290903401986

[14] Cox, D. F. (1967). Risk taking and information handling in consumer behavior. Cambridge, MA.

[15] Cronbach, L. J. (1951). Coefficient alpha and the internal structure of tests. Psychometrika, 16(3), 297-334. doi: 10.1007/bf02310555

[16] Crosby, L. A., Evans, K. R., \& Cowles, D. (1990). Relationship Quality in Services Selling: An Interpersonal Influence Perspective. Journal of Marketing, 54(3), 68-81. doi: $10.1177 / 002224299005400306$

[17] Davis, F. D. (1989). Perceived Usefulness, Perceived Ease of Use, and User Acceptance of Information Technology. MIS Quarterly, 13(3), 319-340. doi: 10.2307/249008

[18] Doll, W. J., \& Torkzadeh, G. (1988). The Measurement of EndUser Computing Satisfaction. MIS Quarterly, 12(2), 259. doi: $10.2307 / 248851$

[19] Fairweather, J. R., \& Campbell, H. (1996). The decision making of organic and conventional agricultural producers.

[20] Hill, R. J., Fishbein, M., \& Ajzen, I. (1977). Belief, Attitude, Intention and Behavior: An Introduction to Theory and Research. Contemporary Sociology, 6(2), 244. doi: 10.2307/2065853

[21] Fornell, C. (1992). A National Customer Satisfaction Barometer: The Swedish Experience. Journal of Marketing, 56(1), 6-21. doi: $10.1177 / 002224299205600103$

[22] Fornell, C., \& Larcker, D. F. (1981). Evaluating Structural Equation Models with Unobservable Variables and Measurement Error. Journal of Marketing Research, 18(1), 39-50. doi: 10.1177/002224378101800104

[23] Fu, J.-R., Farn, C.-K., \& Chao, W.-P. (2006). Acceptance of electronic tax filing: A study of taxpayer intentions. Information \& Management, 43(1), 109-126. doi: 10.1016/j.im.2005.04.001

[24] Gefen, Karahanna, \& Straub. (2003). Trust and TAM in Online Shopping: An Integrated Model. MIS Quarterly, 27(1), 51. doi: 10.2307/30036519

[25] Ghazal, M., Akmal, M., lyanna, S., \& Ghoudi, K. (2016). Smart plugs: Perceived usefulness and satisfaction: Evidence from United Arab Emirates. Renewable and Sustainable Energy Reviews, 55, 1248-1259. doi: 10.1016/j.rser.2015.07.096

[26] Griffiths, J. R., Johnson, F., \& Hartley, R. J. (2007). User satisfaction as a measure of system performance. Journal of Librarianship and Information Science, 39(3), 142-152. doi: 10.1177/0961000607080417

[27] Hamid, A. A., Razak, F. Z. A., Bakar, A. A., \& Abdullah, W. S. W. (2016). The Effects of Perceived Usefulness and Perceived Ease 
of Use on Continuance Intention to Use E-Government. Procedia Economics and Finance, 35, 644-649. doi: 10.1016/s22125671(16)00079-4

[28] Hsu, M.-H., \& Chiu, C.-M. (2004). Predicting electronic service continuance with a decomposed theory of planned behaviour. Behaviour \& Information Technology, 23(5), 359-373. doi: 10.1080/01449290410001669969

[29] Jahroh, S. (2010, June). Organic farming development in Indonesia: lessons learned from organic farming in West Java and North Sumatra. In ISDA 2010 (pp. 11-p). Cirad-InraSupAgro. 00521832/document

[30] Jarvenpaa, S. L., \& Todd, P. A. (1996). Consumer Reactions to Electronic Shopping on the World Wide Web. International Journal of Electronic Commerce, 1(2), 59-88. doi: 10.1080/10864415.1996.11518283

[31] Kaplan, D. (2008). Structural equation modeling: Foundations and extensions (Vol. 10). Sage Publications. https://www.sciencedirect.com/topics/neuroscience/structuralequation-modeling

[32] Kim, B. (2010). An empirical investigation of mobile data service continuance: Incorporating the theory of planned behavior into the expectation-confirmation model. Expert Systems with Applications, 37(10), 7033-7039. doi: 10.1016/j.eswa.2010.03.015

[33] Kim, J., Lee, J., Han, K., \& Lee, M. (2002). Businesses as Buildings: Metrics for the Architectural Quality of Internet Businesses. Information Systems Research, 13(3), 239-254. doi: 10.1287/isre.13.3.239.79

[34] Kim, Y., \& Lee, H. S. (2014). Quality, Perceived Usefulness, User Satisfaction, and Intention to Use: An Empirical Study of Ubiquitous Personal Robot Service. Asian Social Science, 10(11). doi: 10.5539/ass.v10n11p1.

[35] Kuisma, T., Laukkanen, T., \& Hiltunen, M. (2007). Mapping the reasons for resistance to Internet banking: A means-end approach. International Journal of Information Management, 27(2), 75-85. doi: 10.1016/j.ijinfomgt.2006.08.006

[36] Lee, M.-C. (2009). Factors influencing the adoption of internet banking: An integration of TAM and TPB with perceived risk and perceived benefit. Electronic Commerce Research and Applications, 8(3), 130-141. doi: 10.1016/j.elerap.2008.11.006

[37] Lee, T., \& Jun, J. (2007). Contextual perceived value? Business Process Management Journal, 13(6), 798-814. doi: $10.1108 / 14637150710834569$

[38] Lee, Y., \& Kwon, O. (2011). Intimacy, familiarity and continuance intention: An extended expectation-confirmation model in webbased services. Electronic Commerce Research and Applications, 10(3), 342-357. doi: 10.1016/j.elerap.2010.11.005

[39] Li, H., \& Liu, Y. (2014). Understanding post-adoption behaviors of e-service users in the context of online travel services. Information \& Management, 51(8), 1043-1052. doi: 10.1016/j.im.2014.07.004

[40] Li, Y.-M., \& Yeh, Y.-S. (2010). Increasing trust in mobile commerce through design aesthetics. Computers in Human Behavior, 26(4), 673-684. doi: 10.1016/j.chb.2010.01.004

[41] Lin, W.-S., \& Wang, C.-H. (2012). Antecedences to continued intentions of adopting e-learning system in blended learning instruction: A contingency framework based on models of information system success and task-technology fit. Computers \& Education, 58(1), 88-99. doi: 10.1016/j.compedu.2011.07.008

[42] Littler, D., \& Melanthiou, D. (2006). Consumer perceptions of risk and uncertainty and the implications for behaviour towards innovative retail services: The case of Internet Banking. Journal of Retailing and Consumer Services, 13(6), 431-443. doi: 10.1016/j.jretconser.2006.02.006.

[43] Mawhinney, C. H., \& Lederer, A. L. (1990). A study of personal computer utilization by managers. Information \& Management, 18(5), 243-253. doi: 10.1016/0378-7206(90)90026-e

[44] Mayer, R. C., Davis, J. H., \& Schoorman, F. D. (1995). An Integrative Model Of Organizational Trust. Academy of Management Review, 20(3), 709-734. doi: 10.5465/amr.1995.9508080335

[45] Mitchell, V. (1992). Understanding Consumers' Behaviour: Can Perceived Risk Theory Help? Management Decision, 30(3), 2631. doi: $10.1108 / 00251749210013050$

[46] Mitchell, V.W. (1999), "Consumer perceived risk: conceptualizations and models", European Journal of Marketing, Vol. 33 No. 1, pp. 163-95.

[47] Mouakket, S. (2015). Factors influencing continuance intention to use social network sites: The Facebook case. Computers in Human Behavior, 53, 102-110. doi: 10.1016/j.chb.2015.06.045

[48] Nunnally, J. C. (1978). Psychometric theory (2nd edit.) mcgrawhill. Hillsdale, $\mathrm{NJ}, 416$.

[49] Oliver, R. L. (1980). A Cognitive Model of the Antecedents and Consequences of Satisfaction Decisions. Journal of Marketing Research, 17(4), 460-469. doi: 10.1177/002224378001700405

[50] Padel, S. (2001). Conversion to Organic Farming: A Typical Example of the Diffusion of an Innovation? Sociologia Ruralis, 41(1), 40-61. doi: 10.1111/1467-9523.00169

[51] Park, E., Kim, K. J., \& del Pobil, A. P. (2012). An Examination of Psychological Factors Affecting Drivers' Perceptions and Attitudes Toward Car Navigation Systems. Lecture Notes in Electrical Engineering, 555-562. doi: 10.1007/978-94-007-58605_66

[52] Park, N., Rhoads, M., Hou, J., \& Lee, K. M. (2014). Understanding the acceptance of teleconferencing systems among employees: An extension of the technology acceptance model. Computers in Human Behavior, 39, 118-127. doi: 10.1016/j.chb.2014.05.048

[53] Pavlou, P. (2001). Integrating trust in electronic commerce with the technology acceptance model: model development and validation. Amcis 2001 proceedings, 159.

[54] Consumer Acceptance of Electronic Commerce: Integrating Trust and Risk with the Technology Acceptance Model. (2003). International Journal of Electronic Commerce, 7(3), 101-134 doi: 10.1080/10864415.2003.11044275

[55] Rai, A., Lang, S. S., \& Welker, R. B. (2002). Assessing the Validity of IS Success Models: An Empirical Test and Theoretical Analysis. Information Systems Research, 13(1), 50-69. doi: 10.1287/isre.13.1.50.96

[56] Rani, N. S. A., Suradi, Z. U. R. I. N. A. H., \& Yusoff, N. H. (2014). An analysis of technology acceptance model, learning management system attributes, e-satisfaction, and e-retention. International Review of Management and Business Research, 3(4), 1984-1996. https://www.semanticscholar.org/paper/AnAnalysis-of-Technology-Acceptance-Model\%2C-System-RaniSuradi

[57] Rezaei, S., \& Amin, M. (2013). Exploring online repurchase behavioural intention of university students in Malaysia. J. for Global Business Advancement, 6(2), 92. doi: 10.1504/jgba.2013.053561

[58] Rogers, E. M. (2010). Diffusion of innovations. Simon and Schuster.

[59] Saadé, R., \& Bahli, B. (2005). The impact of cognitive absorption on perceived usefulness and perceived ease of use in on-line learning: an extension of the technology acceptance model. Information \& Management, 42(2), 317-327. doi: 10.1016/j.im.2003.12.013

[60] Seddon, P. B., \& Kiew, M. (1994). A partial test and development of DeLone and McLean's model of IS success. Proceedings of the Fifteenth International Conference on Information Systems, Vancouver, Canada, 99-110.

[61] Selnes, F., \& Hansen, H. (2001). The Potential Hazard of SelfService in Developing Customer Loyalty. Journal of Service Research, 4(2), 79-90. doi: 10.1177/109467050142001

[62] Sitkin, S. B., \& Pablo, A. L. (1992). Reconceptualizing the Determinants of Risk Behavior. Academy of Management Review, 17(1), 9-38. doi: 10.5465/amr.1992.4279564

[63] Sjöberg, L., Moen, B. E., \& Rundmo, T. (2004). Explaining risk perception. An evaluation of the psychometric paradigm in risk perception research. Rotunde publikasjoner Rotunde, 84, 55-76.

[64] Söderlund, M., \& Vilgon, M. (1999). Customer satisfaction and 


\section{GENERAL MANAGEMENT}

links to customer profitability: An empirical examination of the association between attitudes and behavior. SSE/EFI Working Paper Series in Business Administration, (1999), 1. https://econpapers.repec.org/paper/hhbhastba/1999_5f001.htm

[65] Stone, R. W., \& Baker-Eveleth, L. (2013). Students' expectation, confirmation, and continuance intention to use electronic textbooks. Computers in Human Behavior, 29(3), 984-990. doi: 10.1016/j.chb.2012.12.007

[66] Suliyanto (2019). The Influence of Market Orientation on Marketing Performances in Micro Small and Medium-Sized (MSMEs) Coconut Sugar Enterprises: The Role of Innovation. Calitatea, 20(172), 143-147. https://www.proquest.com/openview/61ea7483506d23d9c0a0f4 $162 f 9 e 586 \mathrm{~d} / 1$ ?pq-origsite $=$ gscholar $\& \mathrm{cbl}=1046413$

[67] Suliyanto, A. S., \& Jati, D. P. (2013). Potential and Problems of Small Medium Enterprise (SMEs)-coconut-sugar: case study in Banyumas Regency, Central Java-Indonesia. International Journal of Business and Management, 8(3), 18-26. http://dx.doi.org/10.5539/ijbm.v8n3p18

[68] Suliyanto. 2013. Financing Model of Coconut Sugar Micro Small and Medium Enterprises (MSMEs) In Indonesia. International Business and Management. Vol. 7. No.5: pp.410-413

[69] Tessier, J.A., Crouch, W.W. and Atherton, P. (1977) 'New Measures of User Satisfaction with Computer-based Literature Searches', Special Libraries 68: 383-9.

[70] Thong, J. Y. L., Hong, S.-J., \& Tam, K. Y. (2006). The effects of post-adoption beliefs on the expectation-confirmation model for information technology continuance. International Journal of Human-Computer Studies, 64(9), 799-810. doi: 10.1016/j.ijhcs.2006.05.001

[71] Tzavlopoulos, Ioannis, Gotzamani, K., Andronikidis, A., \& Vassiliadis, C. (2019). Determining the impact of e-commerce quality on customers' perceived risk, satisfaction, value and loyalty. International Journal of Quality and Service Sciences, 11(4), 576-587. doi: 10.1108/ijgss-03-2019-0047

[72] Venkatesh, V., \& Davis, F. D. (2000). A Theoretical Extension of the Technology Acceptance Model: Four Longitudinal Field
Studies. Management Science, 46(2), 186-204. doi: 10.1287/mnsc.46.2.186.11926

[73] Venkatesh, Morris, Davis, \& Davis. (2003). User Acceptance of Information Technology: Toward a Unified View. MIS Quarterly, 27(3), 425. doi: $10.2307 / 30036540$

[74] Viehland, D., \& Leong, R. S. Y. (2007). Acceptance and use of mobile payments. ACIS 2007 Proceedings, 16. http://citeseerx.ist.psu.edu/viewdoc/download?doi=10.1.1.87.21 78\&rep=rep $1 \&$ type $=$ pdf

[75] Wang, W., Ngai, E. W. T., \& Wei, H. (2012). Explaining Instant Messaging Continuance Intention: The Role of Personality. International Journal of Human-Computer Interaction, 28(8), 500-510. doi: 10.1080/10447318.2011.622971

[76] Wang, Y.-S., \& Liao, Y.-W. (2007). The conceptualization and measurement of m-commerce user satisfaction. Computers in Human Behavior, 23(1), 381-398. doi: 10.1016/j.chb.2004.10.017

[77] Wen, C., Prybutok, V. R., \& Xu, C. (2011). An integrated model for customer online repurchase intention. Journal of Computer Information Systems, 52(1), 14-23. http://doi.org/ $10.1080 / 08874417.2011 .11645518$

[78] Wixom, B. H., \& Todd, P. A. (2005). A Theoretical Integration of User Satisfaction and Technology Acceptance. Information Systems Research, 16(1), 85-102. doi: 10.1287/isre.1050.0042

[79] Wood, C.M. and Scheer, L.K. (1996), "Incorporating perceived risk into models of consumer deal assessment and purchase intent", in Corfman, K.P. and Lynch, J.G. Jr (Eds), Advances in Consumer Research, Vol. 23, Aassociation for Consumer Research, Provo, UT, pp. 399-406

[80] Zhang, X., \& Prybutok, V. R. (2005). A Consumer Perspective of E-Service Quality. IEEE Transactions on Engineering Management, 52(4), 461-477. doi: 10.1109/tem.2005.856568.

[81] Zhao, Z., \& Cao, Q. (2012). An empirical study on continual usage intention of microblogging: the case of Sina. Nankai Business Review International, 3(4), 413-429. doi: $10.1108 / 20408741211283755$ 


\section{GENERAL MANAGEMENT}

\section{Appendix 1. Measurement}

\begin{tabular}{|c|c|}
\hline \multicolumn{2}{|c|}{ Organic Percieved of Usefulness (OPU) } \\
\hline 1 & Organic coconut sugar business will increase land fertility. \\
\hline 2 & Organic coconut sugar business will increase productivity. \\
\hline 3 & Organic coconut sugar business will decrease production cost. \\
\hline 4 & Organic coconut sugar business will increase income. \\
\hline 5 & Organic coconut sugar business will increase coconut sugar selling price. \\
\hline 6 & Organic coconut sugar business is generally more profitable. \\
\hline \multicolumn{2}{|c|}{ Organic Perceived Ease of Use (OPEU) } \\
\hline 1 & Learning organic coconut sugar cultivation is very easy. \\
\hline 2 & Cultivating organic coconut sugar is clear and easy to understand. \\
\hline 3 & Cultivating organic coconut sugar is very flexible. \\
\hline 4 & Being skilled in the practice of organic coconut sugar cultivation is very easy. \\
\hline 5 & Cultivating organic coconut sugar is easy to practice. \\
\hline \multicolumn{2}{|c|}{ Organic Percieved Risk (OPR) } \\
\hline 1 & Organic coconut sugar cultivation can decrease income. \\
\hline 2 & Organic coconut cultivation causes discomfort/anxiety. \\
\hline 3 & Organic coconut sugar cultivation has production failure risk. \\
\hline 4 & Organic coconut sugar cultivation has marketing failure risk. \\
\hline 5 & Organic coconut sugar cultivation is riskier than the conventional coconut sugar cultivation (non-organic). \\
\hline 6 & Organic coconut sugar cultivation is considering not safe because people have not been done it many times. \\
\hline \multicolumn{2}{|r|}{ Organic Technology User Satisfaction (OTUS) } \\
\hline & Organic coconut sugar technology is as exactly as what I expected. \\
\hline & Organic coconut sugar technology is ideal or very suitable for coconut sugar business. \\
\hline & I am really glad to adopt organic coconut sugar technology. \\
\hline \multicolumn{2}{|r|}{ Organic Continuance Intention $(\mathrm{OCl})$} \\
\hline 1 & I have intention to continue practicing organic coconut sugar cultivation. \\
\hline 2 & I have intention to continue making organic coconut sugar cultivation as a top priority to increase income. \\
\hline 3 & I will routinely recommend organic coconut sugar cultivation to relatives/friends. \\
\hline 4 & I will continue to learn about organic coconut sugar cultivation to develop my business. \\
\hline
\end{tabular}

